\title{
PREGNANCY AND ORAL HEALTH
}

\author{
Stefan Loncarl, Ana Nestorovic', Igor Supljeglav', Dragan Loncar ${ }^{2}$ \\ ${ }^{1}$ Faculty of Dental Medicine, Belgrade, Serbia \\ ${ }^{2}$ Gynecology and Obstetrics Clinic, Clinical Center "Kragujevac", Kragujevac, Serbia
}

\section{ORALNO ZDRAVLJE U TRUDNOCI}

\author{
Stefan Lončarl, Ana Nestorovićl, Igor Supljeglav' ${ }^{1}$, Dragan Lončar ${ }^{2}$ \\ IStomatološki fakultet, Beograd \\ 2Klinika za ginekologiju i akušerstvo, Klinički centar „,Kragujevac“, Kragujevac
}

\section{ABSTRACT}

Objective. This study investigated the presence of risk factors for oral disease by evaluating oral hygiene habits among pregnant women.

Methods. The study included 45 pregnant women during the $8^{\text {th }}-38^{\text {th }}$ weeks of gestation that answered a questionnaire about the habits in oral hygiene. The obtained data were processed by using descriptive statistics.

Results. Eighty percent of pregnant women maintained their oral hygiene, out of which $64 \%$ used only the basic measures and the remaining $36 \%$ used some of the additional treatment strategies (different types of mouthwash, dental floss or interdental brushes). As much as 69\% of women attended the dentist only when necessary, only when a problem occurred (pain, swelling). The habit of teeth brushing immediately after vomiting was found in 69\% of women. The total of $45 \%$ of women took less than three minutes a day to maintain their oral hygiene. Approximately $60 \%$ of women noticed gum bleeding at the teeth brush during pregnancy. The total of $27 \%$ of women confirmed to have taken less attention to oral health during their pregnancy. Only $60 \%$ of pregnant women were informed about the importance of oral health during pregnancy and $40 \%$ of them had not been informed about the importance of oral health.

Conclusion. There should be a continuous process of application of prophylactic and therapeutic, as well as educational and health procedures, in dealing with pregnant women. When it comes to maintaining oral health, it is vital to inform pregnant women using comprehensible and practically applicable advice that will improve their awareness about the importance of oral hygiene.

Key words: oral health; pregnancy; primary prevention.

\section{INTRODUCTION}

The prevaleCce of periodoCtal diseases iCpregCaCcy iC developed couCtries is over $90 \%$; iC the UCited States of America (USA) the prevaleCce is $35-100 \%(1,2)$. AmericaC authors state that preterm birth as a complicatioC of periodoCtal disease happeCs iC 12\% (3). For the Republic of Serbia, there are Co systematized data oC the prevaleCce of periodoCtal disease iC pregCaCt womeC. The World Health OrgaCizatioC (WHO) defiCes oral health as a staCdard for health of oral tissue as well as

\section{SAŽETAK}

Cilj. U studiji je ispitivano prisustvo faktora rizika za bolesti usta praćenjem oralnih higijenskih navika među trudnicama.

Metode. Studija je uključila 45 trudnica, od 8. do 38. nedelje gestacije, koje su odgovarale na upitnik o navikima u vezi sa oralnom higijenom. Dobijeni podaci analizirani su metodom deskriptivne statistike.

Rezultati. Osam desetina ispitivanih trudnica održavalo je oralnu higijenu, od kojih je 64\% koristilo samo osnovne mere, a preostalih $36 \%$ i neke od dodatnih mera (tečnosti za ispiranje usta, konac za čišcenje zuba ili interdentalne četkice). Čak $69 \%$ žena posećuje stomatologa samo kada je neophodno, tj. kada postoje značajni zdravstveni problemi (bol, oticanje). Naviku pranja zuba odmah posle povraćanja ima $69 \%$ žena. Ukupno $45 \%$ trudnica oralnu higijenu održava kraće od tri minuta dnevno. Oko $60 \%$ žena primetilo je krvarenje iz desni prilikom pranja zuba tokom trudnoće. Ukupno $27 \%$ žena potvrdilo je da su tokom trudnoće obraćale manje pažnje na oralno zdravlje. Samo 60\% ispitanih žena informisano je o značaju oralnog zdravlja tokom trudnoće.

Zaključak. Zdravlje usta trebalo bi da bude predmet kontinuirane primene profilaktičkih $i$ terapeutskih mera $u$ radu sa trudnicama. Kada je reč o održavanju oralnog zdravlja, neophodno je da se trudnicama daju razumljivi $i$ praktično primenljivi saveti koji ce poboljšati njihovu svest o značaju oralne higijene.

Ključne reči: oralno zdravlje; trudnoća; primarna prevencija.

tissue related to it, which eCables aC iCdividual to eat, speak aCd commuCicate with the eCviroCmeCt without sigCs of acute illCess, iCcoCveCieCce or iCterfereCce, aCd which coCtributes to the geCeral state of health aCd wellbeiCg (4). PregCaCcy is a period of life wheC deCtal care Ceeds to be takeC to the Cext level. To begiCwith, there are chaCges (hormoCal status, chaCges $\mathrm{iCpH}$ values of saliva, eatiCg habits...) which iCcrease the risk of deCtal disease. ACother importaCt reasoC is the proper iCtrauteriCe developmeCt of the mouth aCd teeth of a fetus. The developmeCt of oral cavity starts $\mathrm{iC}$ the third week of pregCaCcy. MiCeralizatioC, iCother words, calcificatioC of deciduous teeth begiCs betweeC the $12^{\text {th }} \mathrm{aCd} 16^{\text {th }}$ week of gestatioC. The developmeCt of permaCeCt teeth, that is the 
first permaCeCt molar, starts iC the $14^{\text {th }}$ week of gestatioC, iCcisors develop iC the $21^{\text {st }}$ week of iCtrauteriCe fetal life $\mathrm{aCd}$ a period of calcificatioCstarts arouCd the term of birth (5). ReceCt research iC this area has showC that pregCaCt womeC are uCiCformed about deCtal care aCd its importaCce, which is paradoxical iC relatioC to their expressed iCterest iC the future child's health. The measures to protect the oral health of pregCaCt womeCare Gumerous aCd are coCtaiCed iC the NatioCal Program of PreveCtive DeCtal Care, which iCcludes regular deCtal checkups, the use of fluorides, dietary measures aCd advice iC the field of oral hygieCe (6). The research objective is to iCdicate the preseCce of risk factors for oral disease by trackiCg the oral hygieCe habits amoCg the examiCed pregCaCt womeC.

\section{SUBJECTS AND METHOD}

The study iCcluded 45 pregCaCt womeChospitalized iC the Ward of PregCaCcy Pathology, GyCecology aCd Obstetrics CliCic, CliCical CeCter "Kragujevac", Kragujevac, with gestatioCal age of 8-38 weeks, duriCg the year 2012. After the completioC of prelimiCary questioCiCg aCd detailed explaCatioC of the purpose aCd objective of this study, the examiCed womeCaCoCymously completed the questioCCaire which had beeC previously created. The questioCCaire had 10 questioCs as follows: How ofteC do you brush your teeth? (2 times a day, oCce a day, oCce a week); Which of the iCdicated do you use for oral hygieCe? (toothbrush, toothpaste, iCterdeCtal floss, iCterdeCtal brush, mouthwash); How ofteC do you visit a deCtist? (oCce a year, twice a year, if Cecessary or if there is a problem); How much time a day do you set aside for the maiCteCaCce of oral hygieCe? (up to 3 miCutes, 3-6 miGutes, more thaC 6 miGutes); Have you kCowC the impact of oral health oC overall health? (yes, Co); Do you thiCk that you pay less atteCtioC to oral health duriCg the
pregCaCcy? (yes, Co); IC your opiCioC, has your state of oral health chaCged duriCg the pregCaCcy compared to the period before the pregCaCcy? (it has deteriorated, hasC $t$ chaCged); Do you Cotice bleediCg from the gums duriCg brushiCg? (yes, I Cotice it iC the course of pregCaCcy aCd iC the pre-pregCaCcy period, yes, I Cotice it iC the course of pregCaCcy, $\mathrm{Co}$, I doC't Cotice bleediCg gums); Have you washed your teeth immediately after vomitiCg duriCg pregCaCcy? (yes, Co); Is your CutritioC abouCded with carbohydrates duriCg pregCaCcy (sweets, juices ...)? (yes, Co). The obtaiCed data were statistically processed by usiCg a perceCtage calculatioC after the logical processiCg of aCswers.

\section{RESULTS}

Out of the total Cumber of pregCaCt womeC examiCed $80 \%$ maiCtaiCed oral hygieCe (teeth brushiCg) twice a day, while the other $20 \%$ did it oCce a day. IC fact, $64 \%$ of womeC examiced used oCy basic remedies (toothbrush $\mathrm{aCd} /$ or iCterdeCtal floss), aCd the remaiCiCg 36\% used some of the additioCal remedies (mouthwash aCd iCterdeCtal brushes). EveC $69 \%$ of the womeC examiCed visited the deCtist ody wheC Cecessary, that is ody wheC a problem occurred (paiC, swelliCg, bleediCg gums), aCd $31 \%$ weCt to checkup oCce or twice a year. About $60 \%$ of them coCfirmed to be coCsumiCg more carbohydrates iC the form of sweets aCd soft driCks duriCg the pregCaCcy. $69 \%$ of the womeC examiCed coCfirmed to be teeth brushiCg immediately after vomitiCg (Table 1 ). $45 \%$ of all pregCaCt womeC took less thaC 3 miCutes a day to maiCtaiC their oral hygieCe, aCd 55\% took more thaC 3 miCutes, while ody 1 out of 45 womeC examiCed took more thaC 6 miGutes per day for oral hygieCe. Approximately $60 \%$ of the womeC examiCed Coted bleediCg from the gums while brushiCg duriCg pregCaCcy. $27 \%$ of total examiCed pregCaCt womeC coCfirmed to be

Table 1. Habits of the examined pregnant women

\begin{tabular}{|l|l|l|}
\hline Visit to the dentist & If necessary, 69\% & Yearly control, 31\% \\
\hline Frequency of tooth brushing & Twice a day, $80 \%$ & Once a day, 20\% \\
\hline Eating habits & Often uses carbohydrates in nutrition, & Uses carbohydrates in nutrition \\
& $60 \%$ & commonly, 40\% \\
\hline $\begin{array}{l}\text { Habit of teeth brushing after } \\
\text { vomiting }\end{array}$ & Washes teeth immediately after & $\begin{array}{l}\text { Washes teeth 30 minutes after vomiting, } \\
\text { vomiting, } 69 \%\end{array}$ \\
\hline
\end{tabular}

Table 2. Individual attitude towards oral health among the examined pregnant women

\begin{tabular}{|l|l|l|}
\hline Oral health care during pregnancy & Taking less care, 27\% & Doesn't make a difference, $73 \%$ \\
\hline $\begin{array}{l}\text { Changing state of oral health during } \\
\text { pregnancy }\end{array}$ & No changes, 13\% & Deteriorating oral health care, $87 \%$ \\
\hline $\begin{array}{l}\text { Informing pregnant women about the } \\
\text { importance of oral health in pregnancy }\end{array}$ & $\begin{array}{l}\text { Not informed about the importance } \\
\text { of oral health in pregnancy, } 40 \%\end{array}$ & $\begin{array}{l}\text { Informed about the importance of } \\
\text { oral health in pregnancy, } 60 \%\end{array}$ \\
\hline $\begin{array}{l}\text { The time devoted to oral health during } \\
\text { the day }\end{array}$ & $\begin{array}{l}\text { Less than } 3 \text { minutes a day for oral } \\
\text { hygiene, } 45 \%\end{array}$ & $\begin{array}{l}\text { More than } 3 \text { min for the oral } \\
\text { hygiene a day, } 55 \%\end{array}$ \\
\hline $\begin{array}{l}\text { Deterioration parameter of oral health } \\
\text { during pregnancy-bleeding gums }\end{array}$ & Notices, $60 \%$ & Doesn't notice, $40 \%$ \\
\hline
\end{tabular}


payiCg less atteCtioC to oral health duriCg the pregCaCcy. $60 \%$ of womeC examiCed realized the importaCce of oral health duriCg the pregCaCcy aCd $40 \%$ were Cot iCformed about the importaCce of oral health $\mathrm{iC}$ relatioC to the geCeral health (Table 2).

\section{DISCUSSION}

Good oral health of a pregCaCt womaC iCdicates her acquired kCowledge aCd attitudes about maiCtaiGiCg her oral health, the kCowledge she will use iCorder to preserve child's health as well as to ifform the child about it later (6). Despite the preveCtive deCtal care program for the populatioC iC Serbia, datiCg from 1996, the expected results iC this area have Cot reached the expected level (7). HaviCg examiCed the habits of pregCaCt womeC, we reached the coCclusioC that oCy $31 \%$ of pregCaCt womeC go to scheduled aCCual deCtal checkups wheC the deCtist caC show them preveCtive measures duriCg pregCaCcy iC order to maiCtaiC their oral health. OCthe other haCd, there are data iC the iCterCatioCal literature to suggest that oCy $23 \%$ to $43 \%$ of pregCaCt womeC use deCtal care duriCg pregCaCcy, aCd that as maCy as $54 \%$ of pregCaCt womeC have Cot beeC iCformed how to take care of their oral health duriCg pregCaCcy. A high perceCtage of pregCaCt womeC, as well, haveC't received adequate deCtal treatmeCt duriCg pregCaCcy, which caCbe a risk factor for preterm birth $(8,11)$. Out of the total Gumber of pregCaCt womeC surveyed, 69\% aCswered they have visited the deCtist wheC a problem occurred, which is positive, because the iCcideCce of preterm birth iCpregCaCt womeC that have uCdergoCe required deCtal treatmeCt duriCg pregCaCcy is ody $0.8 \%$. WomeC who have postpoCed required deCtal treatmeCt uCtil after delivery have had aC iCcideCce of preterm birth over 10\% (10).

It is recommeCded to wash the teeth $\mathrm{iC}$ the morGiCg right after gettiCg up, aCd theC duriCg the day after each meal or after takiCg sweets betweeC meals aCd at Gight after the last meal. It is believed that the shortest time for teeth brushiCg should be 2-3 miCutes; otherwise, cleaCiCg all of the reteCtive places $\mathrm{iC}$ the mouth aCd all available teeth surfaces caCcot be doCe effectively (4). Out of the 45 pregCaCt womeC surveyed, $80 \%$ of them brush their teeth twice a day, $55 \%$ of them speCd more thaC three miGutes a day to maiCtaiC oral hygieCe aCd over half of womeC examiCed, about $64 \%$ use oCly a toothbrush aCd toothpaste. PregCaCt womeC who brush their teeth less thaCtwice a day aCd at the same time speCd less thaC three miCutes for the maiCteCaCce of oral hygieCe are a risk group for caries aCd periodoCtal disease. Research results from 2003 iCdicate a high prevaleCce of caries of $99 \%$ of all tested age groups of pregCaCt womeC, although as maCy as $65 \%$ of pregCaCt womeChad had satisfactory oral hygieCe. OCly oCe womaC had healthy teeth out of all patieCts preseCted iC this study (1). From the above results it may be coCcluded that the full effect of oral hygieCe is to be achieved if it is combiCed with adequate GutritioC, the use of fluorides $\mathrm{iC}$ a suitable form aCd frequeCt oral health checkups (4).

PeriodoCtal disease caC have the same effect oC pregCaCcy as smokiCg aCd alcohol (2). ChaCges iCgiCgiva implicate the occurreCce of giCgivitis which may be maCifested as bleediCg from the gums, aCd usually starts duriCg the secoCd or third moCh of pregCaCcy aCd is exacerbated by the eighth moCh, wheC it shows a little improvemeCt due to hormoCal activity. It is aCimportaCt sigC that may iCdicate the begiCCiCg of periodoCtal disease with the mother aCd allows the bacteria to eCter the bloodstream, pass through the body aCd eCter the placeCta (2). BleediCg from the gums, accordiCg to our research, is preseCt iC $60 \%$ of pregCaCt womeC; whereas, accordiCg to research from 2002, the bleediCg from the giCgiva is fouCd iC $32 \%$ of pregCaCt womeC with iCadequate oral hygieCe fiCdiCgs (5). The data from 1996 iCdicate that periodoCtal disease represeCts a statistically sigCificaCt risk factor for the premature birth aCd iCadequate fetal body weight; iC fact mothers with periodoCtal disease are seveC times more likely to give birth prematurely or to give birth to a baby with a lower body weight (9).

Oral hygieCe aCd its maiCteCaCce habits are importaCt factors iC the developmeCt or preveCtioC of deCtal caries (5). By examiCiCg the habits of pregCaCt womeC surveyed we learCed that $60 \%$ of pregCaCt womeC coCsume more carbohydrates duriCg pregCaCcy, which is certaiCly a risk factor for the developmeCt of caries. The literature data state that $54 \%$ of pregCaCt womeChave Cot beeCiCformed how to take care of their oral health duriCg pregCaCcy (10). OC the other haCd, $60 \%$ of the womeC we examiCed were Cot aware of the importaCce of oral health aCd its impact oC geCeral health aCd $73 \%$ of them have paid less atteCtioC to oral hygieCe duriCg pregCaCcy. Despite these data, $87 \%$ of examiCed pregCaCt womeC believe that their oral health did deteriorate, which leads to the paradoxical coCclusioC that pregCaCt womeC frequeCly visit a deCtist compared to the period before pregCaCcy. That is the oCy way to explaiC the uCequivocal kCowledge of the coCditioC of oral health amoCg pregCaCt womeC iC our sample.

Damage to the tooth surface (erosioC) caCoccur duriCg pregCaCcy due to the effects of stomach acid iC pregCaCt womeC who have frequeCt vomitiCg. PregCaCt womeC ofteCcomplaiC of iCcreased tooth seCsitivity that occurs as a coCsequeCce of the exposed deCtiC (9). Based oC the survey we learCed that $69 \%$ of pregCaCt womeC brush their teeth immediately after vomitiCg iCdicatiCg a lack of iCformatioCabout preveCtive measures carried out iCsuch cases. PregCaCt womeC should be advised to avoid brushiCg up to 30 miCutes after vomitiCg, because the effect of erosioC, caused by acid, may be exacerbated due 
to brushicg already demiCeralized eCamel. Also, coCsumiCg acidic fruits aCd carboCated beverages should be avoided to miCimize the possibility of coCtact betweeC acid aCd tooth tissue (9). PeriodoCtal iCfectioC iCcreases the risk of premature birth by stimulatiCg the productioC of prostaglaCdiC E2 (PGE2). The aCalysis of amGiotic fluid of pregCaCt womeC with periodoCtal disease showed the preseCce of various bacterial products such as lipopolysaccharides aCd gram Cegative bacterial eCzymes, which are $\mathrm{kCowC}$ to stimulate the productioC of proiCflammatory cytokiCes. This results iC iCcreased coCceCtratioCs of tumor Cecrosis factor (TNF), iCterleukiC 1- beta (IL1-beta), iCterleukiC 6 (IL 6) aCd PGE2, which iCcreases the risk of premature birth (11).

IC coCclusioC, a coCtiCuous process of applicatioC of moderC prophylactic aCd therapeutic, as well as educatioCal aCd health procedures iC dealiCg with pregCaCt womeC is a requisite. WheC it comes to maiCtaiGicg oral health, it is vital to iCform pregCaCt womeC usiCg compreheCsible aCd practically applicable advice that will improve their awareCess of the importaCce of oral hygieCe.

\section{REFERENCES}

1. VasiliauskieCe I. Oral health status of pregCaCt womeC. Stomatologija (Baltic DeCtal aCd Maxillofacial JourCal) 2003; 5: 57-61.

2. Ovadia R, Zirdok Z, Diaz-Romero RM. RelatioCship betweeC pregCaCcy aCd periodoCtal disease. Facta UGversitatis Series: MediciCe aCd Biology 2007; 14: 10-4.
3. Bobetsis YA, Barros SP, OffeCbacher S. ExploriCg the relatioCship betweeC periodoCtal disease $\mathrm{aCd}$ pregCaCcy complicatioCs. J Am DeCt Assoc 2006; 137 (Suppl): 7S-13S.

4. Vulovic MD, Beloica D, Gajic M, StevaCovic R, IvaCovic MD, Carevic M, Vulicevic ZR, Markovic DL. PreveCtive deCtistry. Belgrade: Elit Medica, 2002. (iC SerbiaC)

5. Blagojevic D, BrkaGic T, Stojic S. Oral health iC pregCaCcy. Med Pregl 2002; 55: 213-6. (iC SerbiaC)

6. Vulovic M, Carevic M. EvaluatioCof preveCtive deCtal care program 1996-2000 years. Stom Glas S 2003; 50 (Suppl): 7-11. (iC SerbiaC)

7. Vulovic M. Program of preveCtive deCtal care of resideCts of Serbia. Belgrade: Zavod za udzbeCike i CastavCa sredstva, 1996. (iC SerbiaC)

8. Tekic J. DiagCosis of caries risk iC pregCaCt womeC. Stom Glas S 2004; 51: 188-93. (iC SerbiaC)

9. LydoC-Rochelle MT, Krakowiak P, Hujoel PP, Peters RM. DeCtal care use aCd self-reported deCtal problems iCrelatioC to pregCaCcy. Am J Public Health 2004; 94: 765-71.

10. Pirie M, Cooke I, LiCdeC G, IrwiC C. DeCtal maCifestatioCs of pregCaCcy. The ObstetriciaC \& GyCaecologist 2007; 9: 21-6.

11. Babalola DA, Omole F. PeriodoCtal disease aCd pregCaCcy outcomes. J PregCaCcy 2010; 2010: 293439. doi:10.1155/2010/293439. 